\title{
Hypoxia-regulated target genes implicated in tumor metastasis
}

\author{
Ya-Ping Tsai ${ }^{1}$ and Kou-Juey $\mathrm{Wu}^{1,2,3^{*}}$
}

\begin{abstract}
Hypoxia is an important microenvironmental factor that induces cancer metastasis. Hypoxia/hypoxia-inducible factor-1a (HIF-1a) regulates many important steps of the metastatic processes, especially epithelial-mesenchymal transition (EMT) that is one of the crucial mechanisms to cause early stage of tumor metastasis. To have a better understanding of the mechanism of hypoxia-regulated metastasis, various hypoxia/HIF-1 a-regulated target genes are categorized into different classes including transcription factors, histone modifiers, enzymes, receptors, kinases, small GTPases, transporters, adhesion molecules, surface molecules, membrane proteins, and microRNAs. Different roles of these target genes are described with regards to their relationship to hypoxia-induced metastasis. We hope that this review will provide a framework for further exploration of hypoxia/HIF-1a-regulated target genes and a comprehensive view of the metastatic picture induced by hypoxia.
\end{abstract}

Keywords: Hypoxia, Hypoxia-inducible factor, Target genes, Metastasis, Epithelial-mesenchymal transition

\section{Review}

\section{Introduction}

Hypoxia is a critical microenvironmental factor that is demonstrated to induce tumor metastasis [1-5]. Hypoxia has profound effects in metabolism, angiogenesis, innate immunity, and stemness induction [1]. The effects of hypoxia are usually mediated by hypoxia-inducible factors (HIFs), i.e. HIF- $1 \alpha$ and HIF-2 $\alpha$ [1-4]. HIFs heterodimerize with a common partner, HIF-1 $\beta$ (or aryl hydrocarbon receptor nuclear translocator (ARNT)), to regulate downstream target gene expression through a hypoxia-response element (HRE) [1]. The consensus of HRE is 5'-RCGTG-3', although other sequences were shown to respond to HIFs [3,4]. An ancillary sequence was shown to couple with the canonical HRE to better respond to the binding of HIFs [6]. Although microarray and genomics approaches were performed to identify various downstream targets of HIFs, these targets only represent a small subset of targets reported in the literature [7-10]. More than one thousand target genes were reported to be regulated by HIFs to mediate the effects

\footnotetext{
* Correspondence: kjwu2@ym.edu.tw

'Institute of Biochemistry \& Molecular Biology, National Yang-Ming

University, No.155, Li-Nong St., Sec.2, Peitou, Taipei 112, Taiwan

${ }^{2}$ Head and Neck Cancer Research Program, Cancer Research Center, National Yang-Ming University, No.155, Li-Nong St., Sec.2, Peitou, Taipei 112, Taiwan

Full list of author information is available at the end of the article
}

induced by hypoxia [3,4]. Although most target genes were identified through their regulation by HIF- $1 \alpha$, other targets could be solely regulated by HIF- $2 \alpha[11]$. However, most targets are usually regulated by both HIF- $1 \alpha$ and HIF-2 $\alpha$ [11]. Opposing activities between HIF- $1 \alpha$ and HIF- $2 \alpha$ could occur [11]. Cancer metastasis is the most significant etiology to cause patient death of cancer patients [12]. Different steps are proposed for a tumor cell to become metastatic including epithelialmesenchymal transition (EMT), extracellular matrix modulation, intravasation, circulation, extravasation, homing and the premetastatic niche, and organotropic colonization [5,12]. Due to the causal role of hypoxia in the induction of metastasis [1-5], it will be important to assign the role of these hypoxia-regulated targets according to the various steps of metastasis. In this review, we will focus on the hypoxia/HIF-1 $\alpha$-regulated target genes that are shown to modulate tumor migration, invasion, and metastatic property. These target genes are divided into various categories including transcription factors, chromatin modifiers, enzymes, receptors, small GTPases, transporters, adhesion molecules, surface molecules, membrane proteins, and microRNAs. We hope that this review will provide a framework of hypoxia-regulated targets and further elucidate the

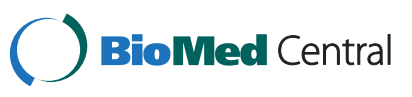


molecular mechanisms to induce metastasis under hypoxic condition.

\section{Transcription factor and histone modifiers}

One well-studied aspect of hypoxia-induced metastasis is that hypoxia induces various transcriptional regulators (also called EMT regulators) to cause EMT [13-16]. The EMT regulators including Twist1, Snail, Slug, ZEB1, ZEB2, and E12/E47 have been shown to be either directly or indirectly regulated by HIF-1 $\alpha$ [17]. These EMT regulators subsequently bind to the promoters of EMT marker genes including E-cadherin, vimentin, and $\mathrm{N}$ cadherin to mediate EMT $[16,17]$. The EMT regulator Snail is a good example of indirect regulation by hypoxia through the lysyl oxidase-like 2 enzyme [18]. The nuclear localization of Snail could also be regulated by ER $\beta$ (estrogen receptor $\beta$ ) to impede EMT in prostate cancer cells [19]. Other transcription factors are also regulated by HIF- $1 \alpha$ to contribute to metastasis. For example, inhibitor of differentiation/DNA binding 2 (ID2) is regulated by HIF- $1 \alpha$ to cause dedifferentiation of neuroblastoma cells, which leads to less mature and more aggressive tumors [20]. Hypoxia upregulates the expression of Ewing Sarcoma-Friend leukemia virus integration 1 (EWS-FLI1) chimeric protein to modulate its transcriptional signature and increase the malignant properties of Ewing's sarcoma cells [21]. Hypoxia activates $\beta$-catenin in hepatocellular carcinoma cells to induce EMT and enhance their metastatic potential [22]. Inverse correlation between the expression of caudal type homeobox 2 (CDX2), a homeodomain protein, and HIF$1 \alpha$ is observed in colorectal cancer samples [23]. Finally, hypoxia converts the inhibitor function of SMAD family member 7 (SMAD7, an inhibitor of the TGF- $\beta$ signaling pathway) into a promoter of cell invasion [24]. In addition to transcriptional factors, chromatin modifiers could also be regulated by hypoxia. Induction of histone lysine-specific demethylase 4B (KDM4B, JMJD2B) correlates with invasion and advanced clinical stage in colorectal cancers [25]. JMJD2B also plays a central role in gastric cancer cell growth [26]. JMJD2C (KDM4C) is induced by HIF- $1 \alpha$ to mediate epigenetic regulation of HIF- $1 \alpha$ downstream genes involved in metabolic reprogramming and lung metastasis of breast cancer [27]. The histone methyltransferase mixed lineage leukemia 1 (MLL1) is induced by hypoxia to enhance hypoxic response [28]. All these results demonstrated that hypoxia/HIF- $1 \alpha$ regulates both transcription factors and chromatin modifiers to induce metastasis in an EMTdependent or independent manner.

\section{Enzymes that are regulated by hypoxia/HIF-1a}

Hypoxia/HIF- $1 \alpha$ is originally shown to regulate the expression of metalloproteases including matrix metalloprotease-1 (MMP1) and MMP3 to induce metastasis [29]. In contrast, HIF- $2 \alpha$ activates the expression of membrane type-1 matrix metalloproteinase (MT1MMP) in von Hippel-Lindau renal cell carcinoma $[29,30]$. The most significant enzyme that is regulated by hypoxia to cause metastasis is lysyl oxidase (LOX) [31]. Secreted LOX is required for adhesion interactions necessary for migration through focal adhesion kinase activity and cell to matrix adhesion [31]. Lysyl oxidase is also a crucial mediator of bone marrow cell recruitment to form the premetastatic niche through crosslinking collagen IV and recruiting CD11b myeloid cells [32]. Other lysyl oxidase-like enzymes that are regulated by HIF- $1 \alpha$ also play an important role in the formation of breast cancer metastatic niche [33]. Loss of programmed cell death $4(\operatorname{Pdcd} 4)$, a tumor suppressor, increases the expression of lysyl oxidase and hypoxia-induced breast cancer cell invasion through a HIF-1-independent mechanism [34]. A disintegrin and metalloproteinase with thrombospondin motifs 1 (ADAMTS1) is a hypoxic early response gene in endothelial cells that promotes migration under hypoxia [35]. Hypoxia activates the expression of angiotensin converting enzyme (ACE) and inhibits ACE2 expression in human pulmonary smooth muscle cells [36]. Sulfatase 1 (Hsulf-1) modulates the sulfation state of heparin sulfate proteoglycans and hypoxia represses Hsulf-1 expression that leads to increased bFGF signaling and the promotion of migration and invasion of breast cancer cells [37]. Hypoxia promotes isocitrate dehydrogenase (IDH2)-dependent carboxylation of $\alpha$-ketoglutarate to support cell growth and viability [38]. HIF- $1 \alpha$ regulates xeroderma pigmentosum, complementation group A (XPA) expression and contributed to cisplatin resistance in lung cancer [39]. The results described above indicate that various enzymes are regulated by hypoxia/HIF-1 $\alpha$ to regulate the metastatic activity of tumor cells.

\section{Receptors, kinases, small GTPases, and transporters}

Various receptors, receptor-activated kinases, small GTPases, and transporters are regulated by hypoxia/ HIF- $1 \alpha$ to play a significant role in cancer metastasis. For example, chemokine receptor 4 (CXCR4) is one of the early identified hypoxia/HIF- $1 \alpha$ target genes that mediates hypoxia-induced angiogenesis and metastasis [40]. Similar regulation of another chemokine receptor, chemokine (C-X3-C motif) receptor 1 (CX3CR1), is also shown in prostate cancer and pancreatic ductal adenocarcinoma cells to mediate their migration and invasion $[41,42]$. Notch signaling has recently been shown to be required for hypoxia-induced EMT, tumor cell migration and invasion through activation of Snail [43]. The urokinase-type plasminogen activator receptor (UPAR) is activated by HIF- $1 \alpha$ and is crucial for hypoxia-induced 
metastasis [44]. Similarly, plasminogen activator inhibitor-1 (PAI-1), a factor related to the uPAR system that predicts poor prognosis in many cancers, is regulated by hypoxia through the cooperative functions of HIF-1 $\alpha$, Egr-1, and C/EBP $\alpha$ [45]. The 67-kDa laminin receptor was shown to be activated by hypoxia to promote gastric cancer metastasis through increasing uPA and MMP9 expession [46]. Toll-like receptor 4 (TLR4) is induced by HIF- $1 \alpha$ to promote pancreatic tumor cell growth [47]. C-Met protooncogene expression is regulated by hypoxia to enhance scatter factor/hepatocyte growth factor (SF/HGF)-induced cell migration and invasion in glioma and trophoblast cells $[48,49]$. Pericyte depletion triggers hypoxia-induced EMT and metastasis through the c-Met signaling [50]. RON tyrosine kinase is a direct target of HIF- $1 \alpha$ and mediates invasion of breast carcinoma cells [51]. Nitric oxide-induced macrophage migration is mediated through HIF-1 $\alpha$-regulated small GTPases Cdc42 and Rac1 [52]. RhoE activation by HIF$1 \alpha$ mediates hypoxia-induced EMT of gastric cancer cells [53]. Insulin receptor substrate 2 (IRS-2) is regulated by hypoxia to promote breast carcinoma cell survival and invasion [54]. Different transporters including glucose transporter type 1 (glut-1) and multidrug resistance protein 1 (MDR1) are regulated by hypoxia/HIF-1 $\alpha$ and implicated in the metastatic processes [55,56]. A truncated form of the voltage-dependent anion channel 1 (VDAC1) is induced by HIF- $1 \alpha$ to promote cancer cell survival and correlates with chemotherapy resistance in lung cancer patients [57].

\section{Adhesion molecules, surface molecules, membrane proteins, and various proteins implicated in hypoxia-induced metastasis}

Various adhesion or surface molecules, membrane proteins, and miscellaneous proteins are regulated by hypoxia/HIF- $1 \alpha$ and involved in hypoxia-induced metastasis. For breast cancer, angiopoietin-like 4 (ANGPTL4) and L1 cell adhesion molecule (L1CAM) are the two important molecules that mediate vascular metastasis of hypoxic breast cancer cells to the lungs [58]. ANGPTL4 inhibits EC (endothelial cell)-EC interactions, whereas L1CAM promotes the adherence of breast cancer cells to ECs [58]. HIF-1 $\alpha$ mediates anoikis resistance through suppression of $\alpha 5$ integrin [59]. CD151, a member of the tetraspanin family that plays a role in cell adhesion and motility, is repressed by hypoxia to regulate the detachment of colorectal cancer cells from the primary site and homing in the second site [60]. CD24, a cancer stem cell-associated membrane protein, is an effector of HIF-1 $\alpha$-driven primary tumor growth and metastasis [61]. CD147 is induced by HIF$1 \alpha$ and Sp1 to promote glycolysis and tumor progression in epithelial solid tumors [62]. Galectin-1, one of the important lectins contributing to malignant tumor formation, is induced by HIF- $1 \alpha$ to mediate migration and invasion of colorectal cancer cells [63]. MUC1, an O-glycoprotein membrane-bound mucin, is a HIF- $1 \alpha$ target that plays a role in regulating the migration and invasive property of renal cell carcinoma cells [64]. Semaphorin $4 \mathrm{D}$ is induced by HIF- $1 \alpha$ to promote angiogenesis and enhance tumor invasive growth of head and neck cancers [65]. Caveolin-1, an essential structural constituent of caveolae on the cell membrane involved in endocytosis, is upregulated by HIF- $1 \alpha$ to promote ligandindependent EGF receptor signaling and increase the cell proliferative, migratory, and invasive capacities [66]. Human enhancer of filamentation 1 (HEF1, NEDD9, Cas-L), a scaffold protein implicated in cellular attachment and motility, is a mediator of HIF-1 $\alpha$-induced migration in colorectal carcinoma cells [67]. Liprin- $\alpha 4$ is a HIF-1 $\alpha$-regulated cytoplasmic protein required for maintenance of cell-cell contacts in renal cell carcinoma [68]. Two matricellular proteins CYR61 (CCN1) and NOV (CCN3) are regulated by HIF- $1 \alpha$ and TGF- $\beta 3$ in human trophoblasts and increase their migration and invasion [69]. Prostate specific antigen (PSA), one of the androgen receptor target genes involved in tumor invasion, is induced by HIF-1 $\alpha$ in prostate cancers [70]. Finally, proteomics experiments identify two HIF-1-inducible targets (S100A4, CapG) and S100A4 is involved in migration and invasion of cancer cells [71]. It is obvious that various types of proteins can play a significant role in mediating hypoxia-induced migration and invasive property of cancer cells.

\section{microRNA targets}

Various microRNAs are shown to be regulated by hypoxia/HIF-1 $\alpha$. A recent review describing the various microRNAs regulated by hypoxia provides a concise summary of the roles of these microRNAs in metabolism, DNA damage response, and angiogenesis [72]. However, the role of these microRNAs in metastasis was not elucidated in this review. Among the microRNAs regulated by hypoxia, miR-210 is the critical microRNA implicated in tumor initiation and metastatic potential by targeting different downstream molecules including genes expressed under normoxia and vacuole membrane protein 1 (VMP1) [73,74]. MiR-210 is proposed to be a micromanager of the hypoxia pathway [75]. Reversioninducing-cysteine-rich protein with kazal motifs (RECK) is regulated by both hypoxia and Ras-signaling pathways through three groups of microRNAs (miR-15b/16, miR21, and miR-372/373) [76]. Hypoxia represses miR-34a that targets the Notch signaling pathway and promotes EMT in tubular epithelial cells [77]. HIF- $\alpha$ downregulates miR-17/20a that targets p21 and signal transducer and activator of transcription 3 (STAT3) and inhibited 
Table 1 Classification of the hypoxia-regulated genes

\begin{tabular}{|c|c|c|}
\hline Biological function & Gene symbol/ alias & References \\
\hline Transcription factors & Twist1, Snail, Slug, ZEB1, ZEB2, E12/E47, ID2,EWS-FLI1, $\beta$-catenin, CDX2, SMAD7 & {$[13-16,20-24]$} \\
\hline Histone modifiers & JMJD2B, JMJD2C, MLL1 & {$[25-28]$} \\
\hline Enzymes & MMP1, MMP3, MT1-MMP, LOX, ADAMTS1, ACE, ACE2, Hsulf-1, IDH2, XPA & {$[29-33,35-39]$} \\
\hline Receptors, receptor-associated kinase & $\begin{array}{l}\text { CXCR4, CX3CR1, Notch, uPAR, PAl-1, 67-kDa laminin receptor, TLR4, c-Met, } \\
\text { RON tyrosine kinase }\end{array}$ & [40-51] \\
\hline small GTPases, intracellular signaling molecules & Cdc42, Rac1, RhoE, IRS-2 & {$[52-54]$} \\
\hline Transporters & glut-1, MDR1, VDAC1 & {$[55-57]$} \\
\hline Membrane proteins & $\begin{array}{l}\text { ANGPTL4, L1CAM, a5 integrin, CD151, CD24, CD147, Galectin-1, MUC1, } \\
\text { Semaphorin 4D, Caveolin-1 }\end{array}$ & {$[58-66]$} \\
\hline Scaffold protein, cytoplasmic protein & HEF1, Liprin-a4 & {$[67,68]$} \\
\hline Matricellular proteins & CYR61, NOV & [69] \\
\hline microRNAs & $\begin{array}{l}\text { miR-210, miR-15b/16, miR-21, miR-372/373, miR-34a, miR-17/20a, miR-103/107, } \\
\text { miR-126 }\end{array}$ & [73-80] \\
\hline
\end{tabular}

AML cell differentiation [78]. Finally, hypoxia-induced miR-103/107 targets the tumor suppressors deathassociated protein kinase (DAPK) and Kruppel-like factor 4 (KLF4) to promote metastasis of colorectal cancer [79]. MiR-107 is also induced by p53 to repress the expression of HIF-1 $\beta$ and suppress tumor growth and angiogenesis [80]. Recent deep sequencing experiments to search for microRNAs regulated by hypoxia resulted in the discovery of known and novel microRNAs [81]. MiR-210 is still the prominent microRNA that was identified under hypoxia together with other known microRNAs (e.g. miR-126) and novel microRNAs. The role of these newly discovered microRNAs in metastasis remains to be determined.

\section{Conclusions}

Hypoxia is one of the most important environmental factors that induce cancer metastasis. Hypoxia-regulated biological effects have been extensively investigated. It is obvious that hypoxia regulates key steps of the metastatic process. Through outlining various targets regulated by hypoxia/HIF- $1 \alpha$ to mediate tumor metastasis, the review wishes to provide a comprehensive guide according to the various categories described. A summary of all these targets is listed in Table 1. Although angiogenesis is regulated by hypoxia and can contribute to tumor metastasis $[1,2]$, the review only focuses on the targets related to the various steps controlling metastasis [5]. In addition, various targets regulated by hypoxia/ HIF- $1 \alpha$ to mediate other biological effects such as metabolism may also contribute to metastasis $[1,2]$. The functions mediated by these targets related to metabolism need to be verified using the in vitro and in vivo metastatic assays to demonstrate their contribution to tumor metastatic activity. The linkage between metabolism and tumor metastasis remains to be further explored. The concept will also apply to other hypoxia/
HIF-1 $\alpha$-regulated targets that appear not to be directly regulating metastasis.

From this review, it appears that different categories of targets can contribute to the metastatic process. Judging from the various steps involved in tumor metastasis, it is not surprising. However, it will need further investigation to figure out the exact mechanisms of how these targets contribute to metastasis. In addition, the interacting roles played by these targets to mediate metastasis will also require an integrated approach to combine molecular biology and systems biology in order to put all these players into a more comprehensive picture. Furthermore, novel hypoxia/HIF-1 $\alpha$-regulated targets that can mediate metastasis will need to be identified in order to complete the full picture of tumor metastasis induced by hypoxia/HIF-1 $\alpha$. Finally, elucidation of the functions of these targets mediating metastasis will provide the possibility of using these targets as therapeutic venues to improve the treatment of hypoxia-induced tumors.

\section{Abbreviations}

HIF-1: Hypoxia-inducible factor-1; EMT: Epithelial-mesenchymal transition; ARNT: Aryl hydrocarbon receptor nuclear translocator; EWS-FLI1: Ewing Sarcoma-Friend leukemia virus integration 1; CDX2: Caudal type homeobox 2; SMAD7: SMAD family member 7; JMJD2B (KDM4B): Lysine-specific demethylase 4B; ACE: Angiotensin converting enzyme; CX3CR1: Chemokine (C-X3-C motif) receptor 1; IRS-2: Insulin receptor substrate 2; glut-1: Glucose transporter type 1; MDR1: Multidrug resistance protein 1; ID2: Inhibitor of differentiation/DNA binding 2; MMP: Matrix metalloprotease; LOX: Lysyl oxidase; ADAMTS1: A disintegrin and metalloproteinase with thrombospondin motifs 1; pdcd4: Programmed cell death 4; ANGPTL4: Angiopoietin-like 4; L1CAM: L1 cell adhesion molecule; RECK: Reversion-inducing-cysteine-rich protein with kazal motifs; STAT3: Signal transducer and activator of transcription 3; DAPK: Deathassociated protein kinase; KLF4: Kruppel-like factor 4; Hsulf-1: sulfatase 1; XPA: Xeroderma pigmentosum, complementation group A; SF/HGF: Scatter factor/hepatocyte growth factor.

\section{Competing interests}

The authors declare that they have no competing interests. 


\section{Authors' contributions}

KJW completed the final draft and revision of the manuscript. Both authors read and approved the final manuscript.

\section{Acknowledgments}

We apologize to the authors whose work could not be cited due to the space constraint of reference citation. We declare no competing financial interests. This work was supported in part to K.J.W. by National Science Council Frontier grant (NSC101-2321-B-010-002), National Research Program for Biopharmaceuticals (NSC101-2325-B-010-004), a grant from Ministry of Education, Aim for the Top University Plan (101AC-T505), center of excellence for cancer research at Taipei Veterans General Hospital (DOH101TD-C-111-007), Taichung Veterans General Hospital (TCVGH-YM1000301, TCVGH-YM1010301), and National Health Research Institutes (NHRI-EX1019931B|).

\section{Author details}

${ }^{1}$ Institute of Biochemistry \& Molecular Biology, National Yang-Ming University, No.155, Li-Nong St., Sec.2, Peitou, Taipei 112, Taiwan. ${ }^{2}$ Head and Neck Cancer Research Program, Cancer Research Center, National Yang-Ming University, No.155, Li-Nong St., Sec.2, Peitou, Taipei 112, Taiwan. ${ }^{3}$ Genome Research Center, National Yang-Ming University, Taipei 112, Taiwan.

Received: 1 October 2012 Accepted: 5 December 2012

Published: 14 December 2012

\section{References}

1. Majmundar AJ, Wong WJ, Simon MC: Hypoxia-inducible factors and the response to hypoxic stress. Mol Cell 2010, 40:294-309.

2. Bertout JA, Patel SA, Simon MC: The impact of $\mathrm{O} 2$ availability on human cancer. Nat Rev Cancer 2008, 8:967-975.

3. Semenza GL: Hypoxia-inducible factors: mediators of cancer progression and targets for cancer therapy. Trends Pharmacol Sci 2012, 33:207-214.

4. Semenza GL: Molecular mechanisms mediating metastasis of hypoxic breast cancer cells. Trends Mol Med 2012, 18:534-543.

5. Lu X, Kang Y: Hypoxia and hypoxia-inducible factors: master regulators of metastasis. Clin Cancer Res 2011, 16:5928-5935.

6. Kimura H, Weisz A, Ogura T, Hitomi Y, Kurashima Y, Hashimoto K, D'Acquisto $F$, Makuuchi M, Esumi H: Identification of hypoxia-inducible factor 1 ancillary sequence and its function in vascular endothelial growth factor gene induction by hypoxia and nitric oxide. J Biol Chem 2001, 276:2292-2298.

7. Krishnamachary B, Berg-Dixon S, Kelly B, Agani F, Feldser D, Ferreira G, lyer N, LaRusch J, Pak B, Taghavi P, Semenza GL: Regulation of colon carcinoma cell invasion by hypoxia-inducible factor-1. Cancer Res 2003, 63:1138-1143

8. Wang V, Davis DA, Haque M, Huang LE, Yarchoan R: Differential gene upregulation by hypoxia-inducible factor-1a and hypoxia-inducible factor2a in HEK293T cells. Cancer Res 2005, 65:3299-3306.

9. Gaber T, Haupl T, Sandig G, Tykwinska K, Fangradt M, Tschirschmann M, Hahne M, Dziuria R, Erekul K, Lautenbach M, Kolar P, Burmester GR, Buttgereit F: Adaptation of human CD4+ T cells pathophysiological hypoxia: a transcriptome analysis. J Rheumatol 2009, 36:2655-2669.

10. Benita Y, Kikuchi $H$, Smith AD, Zhang MQ, Chung DC, Xavier RJ: An integrative genomics approach identifies hypoxia-inducible factor- 1 (HIF-1)-target genes that form the core response to hypoxia. Nucleic Acids Res 2009, 37:4587-4602.

11. Keith B, Johnson RS, Simon MC: HIF1a and HIF2a: sibling rivalry in hypoxic tumour growth and progression. Nat Rev Cancer 2012, 12:9-22.

12. Gupta GP, Massague J: Cancer metastasis: building a framework. Cell 2006, 127:679-695.

13. Krishnamachary B, Zagzag D, Nagasawa H, Rainey K, Okuyama H, Baek JH, Semenza GL: Hypoxia-inducible factor-1-dependent repression of E-cadherin in von Hippel-Lindau tumor suppressor-null renal carcinoma mediated by TCF3, ZFHX1A, and ZFHX1B. Cancer Res 2006, 66:2725-2731.

14. Evans AJ, Russell RC, Roche O, Burry NT, Fish JE, Chow WW, Kim WY, Saravanan A, Maynard MA, Gervais ML, Sufan RI, Roberts AM, Wilson LA, Betten M, Vandewalle C, Berx G, Marsden PA, Irwin MS, The BT, Jewett MA Ohh M: VHL promotes E2 box-dependent E-cadherin transcription by HIF-mediated regulation of SIP1 and Snail. Mol Cell Biol 2007, 27:157-169.
15. Yang MH, Wu MZ, Chiou SH, Chen PM, Chang SY, Teng SC, Wu KJ: Direct regulation of TWIST by HIF-1a promotes metastasis. Nat Cell Biol 2008, 10:295-305

16. Peinado $\mathrm{H}$, Olmeda D, Cano A: Snail, Zeb and bHLH factors in tumour progression: an alliance against the epithelial phenotype? Nat Rev Cancer 2007, 7:415-428.

17. Yang MH, Wu KJ: TWIST activation by hypoxia inducible factor-1 (HIF-1): implications in metastasis and development. Cell Cycle 2008, 7:2090-2096.

18. Peinado H, la Cruz MC I-d, Olmeda D, Csiszar K, Fong KSK, Vega S, Nieto MA, Cano A, Portillo F: A molecular role for lyxyl oxidase-like 2 enzyme in Snail regulation and tumor progression. EMBO J 2005, 24:3446-3458.

19. Mak P, Leav I, Pursell B, Bae D, Yang X, Taglienti CA, Gouvin LM, Sharma VM, Mercurio AM: ER $\beta$ impedes prostate cancer EMT by destabilizing HIF-1a and inhibiting VEGF-mediated snail nuclear localization: implication for Gleason grading. Cancer Cell 2010, 17:319-332.

20. Lofstedt T, Jogi A, Sigvardsson M, Gradin K, Poellinger L, Pahlman S, Axelson $\mathrm{H}$ : Induction of ID2 expression by hypoxia-inducible factor-1: a role in dedifferentiation of hypoxic neuroblastoma cells. J Biol Chem 2004, 279:39223-39231.

21. Aryee DN, Niedan S, Kauer M, Schwentner R, Bennani-Baiti IM, Ban J, Muehlbacher K, Kreppel M, Walker RL, Meltzer P, Poremba C, Kofler R, Kovar $\mathrm{H}$ : Hypoxia modulates EWS-FLI1 transcriptional signature and enhances the malignant properties of Ewing's sarcoma cells in vitro. Cancer Res 2010, 70:4015-4023.

22. Liu L, Zhu XD, Wang WQ, Shen $Y$, Qin $Y$, Ren ZG, Sun HC, Tang ZY: Activation of $\beta$-catenin by hypoxia in hepatocellular carcinoma contributes to enhanced metastatic potential and poor prognosis. Clin Cancer Res 2010, 16:2740-2750.

23. Zheng J, Sun X, Wang W, Lu S: Hypoxia-inducible factor-1a modulates the down-regulation of the homeodomain protein CDX2 in colorectal cancer. Oncol Rep 2010, 24:97-104.

24. Heikkinen PT, Nummela M, Jokilehto T, Grenman R, Kahari VM, Jaakkola PM: Hypoxic conversion of SMAD7 function from an inhibitor into a promoter of cell invasion. Cancer Res 2010, 70:5984-5993.

25. Fu L, Chen L, Yang J, Ye T, Chen Y, Fang J: HIF-1a-induced histone demethylase JMJD2B contributes to the malignant phenotype of colorectal cancer cells via an epigenetic mechanism. Carcinogenesis 2012, 33:1664-1673.

26. Kim JG, Yi JM, Park SJ, Kim JS, Son TG, Yang K, Yoo MA, Heo K: Histone demethylase JMJD2B-mediated cell proliferation regulated by hypoxia and radiation in gastric cancer cell. Biochim Biophys Acta 2010, 1819:1200-1207.

27. Luo W, Chang R, Zhong J, Pandey A, Semenza GL: Histone demethylase JMJD2C is a coactivator for hypoxia-inducible factor 1 that is required for breast cancer progression. Proc Natl Acad Sci USA 2012 109:E3367-E3376.

28. Heddleston JM, Wu Q, Rivera M, Minhas S, Lathia JD, Sloan AE, lliopoulos O, Hjelmeland AB, Rich JN: Hypoxia-induced mixed-lineage leukemia 1 regulates glioma stem cell tumorigenic potential. Cell Death Differ 2012, 19:428-439.

29. Lin JL, Wang MJ, Lee D, Liang CC, Lin S: Hypoxia-inducible factor-1a regulates matrix metalloprotease-1 activity in human bone marrowderived mesenchymal stem cells. FEBS Lett 2008, 582:2615-2619.

30. Petrella BL, Lohi J, Brinckerhoff CE: Identification of membrane type-1 matrix metalloproteinase as a target of hypoxia-inducible factor-2a in von Hippel-Lindau renal cell carcinoma. Oncogene 2005 24:1043-1052

31. Erler JT, Bennewith EL, Nicolau M, Dornhofer N, Kong C, Le QT, Chi JT, Jeffrey SS, Giaccia AJ: Lysyl oxidase is essential for hypoxia-induced metastasis. Nature 2006, 440:1222-1226.

32. Erler JT, Bennewith KL, Cox TR, Lang G, Bird D, Koong A, Le QT, Giaccia AJ: Hypoxia-induced lysyl oxidase is a critical mediator of bone marrow cell recruitment to form the premetastatic niche. Cancer Cell 2009 15:35-44.

33. Wong CC, Gilkes DM, Zhang $H$, Chen J, Wei $H$, Chaturvedi P, Fraley SI, Wong CM, Khoo US, Ng IO, Wirtz D, Semenza GL: Hypoxia-inducible factor 1 is a master regulator of breast cancer metastatic niche formation. Proc Natl Acad Sci USA 2011, 108:16369-16374.

34. Santhanam AN, Baker AR, Hegamyer G, Kirschmann DA, Colburn NH: Pdcd4 repression of lysyl oxidase inhibits hypoxia-induced breast cancer cell invasion. Oncogene 2010, 29:3921-3932. 
35. Hatipoglu OF, Hirohata S, Cilek MZ, Ogawa H, Miyoshi T, Obika M, Demircan K, Shinohata R, Kusachi S, Nonomiya Y: ADAMTS1 is a unique hypoxic early response gene expressed by endothelial cells. J Biol Chem 2009, 284:16325-16333.

36. Zhang R, Wu Y, Zhao M, Liu C, Zhou L, Shen S, Liao S, Yang K, Li Q, Wan H: Role of HIF-1a in the regulation of ACE and ACE2 expression in hypoxic human pulmonary artery smooth muscle cells. Am J Physiol Lung Cell Mo Physiol 2009, 297:L631-L640.

37. Khurana A, Liu P, Mellone P, Lorenzon L, Vincenzi B, Datta K, Yang B, Linhardt RJ, Lingle W, Chien J, Baldi A, Shridhar V: HSulf-1 modulates GFG2- and hypoxia-mediated migration and invasion of breast cancer cells. Cancer Res 2011, 71:2152-2161.

38. Wise DR, Ward PS, Shay JE, Cross JR, Gruber JJ, Sachdeva UM, Platt JM, Dematteo RG, Simon MC, Thompson CB: Hypoxia promotes isocitrate dehydrogenase-dependent carboxylation of a-ketoglutarate to citrate to support cell growth and viability. Proc Natl Acad Sci USA 2011, 108:19611-19616.

39. Liu Y, Bernauer AM, Yingling CM, Belinsky SA: HIF1a regulated expression of XPA contributes to cisplatin resistance in lung cancer. Carcinogenesis 2012, 33:1187-1192.

40. Staller P, Sulitkova J, Lisztwan J, Moch H, Oakeley EJ, Krek W: Chemokine receptor CXCR4 downregulated by von Hippel-Lindau tumor suppressor pVHL. Nature 2003, 425:307-311.

41. Xiao LJ, Chen YY, Lin P, Zou HF, Lin F, Zhao LN, Li D, Guo L, Tang JB, Zheng $X \mathrm{~L}$, YU XG: Hypoxia increases CX3CR1 expression via HIF-1 and NF-kB in androgen-independent prostate cancer cells. Int J Oncol 2012, 41:1827-1836

42. Zhao T, Gao S, Wang X, Liu J, Duan Y, Yuan Z, Sheng J, Li S, Wang F, Yu M, Ren $\mathrm{H}$, Hao J: Hypoxia-inducible factor- 1 a regulates chemotactic migration of pancreatic ductal adenocarcinoma cells through directly transactivating the CX3CR1 gene. PLOS One 2012, 7:e43399.

43. Sahlgren C, Gustafsson MV, Jin S, Poellinger L, Lendahl U: Notch signaling mediates hypoxia-induced tumor cell migration and invasion. Proc Natl Acad Sci USA 2008, 105:6392-6397.

44. Buchler P, Reber HA, Tomlinson JS, Hankinson O, Kallifatidis G, Friess H, Herr I, Hines OJ: Transcriptional regulation of urokinase-type plasminogen activator receptor by hypoxia-inducible factor 1 is crucial for invasion of pancreatic and liver cancer. Neoplasia 2009, 11:1196-1206.

45. Liao H, Hyman MC, Lawrence DA, Pinsky DJ: Molecular regulation of the PAl-1 gene by hypoxia: contributions of Egr-1, HIF-1a, and C/EBPa. FASEB J 2007, 21:935-949.

46. Liu L, Sun L, Zhao P, Yao L, Jin H, Liang S, Wang Y, Zhang D, Pang Y, Shi Y, Chai $\mathrm{N}$, Zhang $\mathrm{H}$, Zhang $\mathrm{H}$ : Hypoxia promotes metastasis in human gastric cancer by up-regulating the $67-\mathrm{kDa}$ laminin receptor. Cancer Sci 2010, 10:1653-1660.

47. Fan P, Zhang JJ, Wang B, Wu HQ, Zhou SX, Wang CY, Zhang JH, Tian Y, Wu HS: Hypoxia-inducible factor-1 up-regulates the expression of Toll-like receptor 4 in pancreatic cancer cells under hypoxic conditions. Pancreatology 2012, 12:170-178.

48. Eckerich C, Zapf S, Fillbrandt R, Loges S, Westphal M, Lamszus K: Hypoxia can induce c-Met expression in glioma cells and enhance SF/HGF-induced cell migration. Int J Cancer 2007, 121:276-283.

49. Hayashi M, Sakata M, Takeda T, Tahara M, Yamamoto T, Okamoto Y, Minekawa R, Isobe A, Ohmichi M, Tasaka K, Murata Y: Up-regulation of c-met protooncogene product expression through hypoxia-inducible factor-1a is involved in trophoblast invasion under low-oxygen tension. Endocrinology 2005, 146:4682-4689.

50. Cooke VG, LeBleu VS, Keskin D, Khan Z, O'Connell JT, Teng Y, Duncan MB, Xie L, Maeda G, Vong S, Sugimoto H, Rocha RM, Damascena A, Brentani RR, Kalluri R: Pericyte depletion results in hypoxia-associated epithelial-tomesenchymal transition and metastasis mediated by Met signaling pathway. Cancer Cell 2012, 21:66-81.

51. Thangasamy A, Rogge J, Ammanamanchi S: RON tyrosine kinase is a direct target of HIF-1 a mediated invasion of breast carcinoma cells. J Biol Chem 2009, 283:5335-5343.

52. Zhou J, Dehne N, Brune B: Nitric oxide causes macrophage migration via HIF-1-stimulated small GTPases Cdc42/Rac1. Free Radic Biol Med 2009, 47:741-749

53. Zhou J, Li K, Gu Y, Feng B, Ren G, Zhang L, Wang Y, Nie Y, Fan D: Transcriptional up-regulation of RhoE by hypoxia-inducible epithelial to mesenchymal transition of gastric cancer cells. Biochem Biophys Res Commun 2011, 415:348-354.

54. Mardilovich K, Shaw LM: Hypoxia regulates insulin receptor substrate-2 expression to promote breast carcinoma cell survival and invasion. Cancer Res 2009, 69:8894-8901.

55. Airley R, Loncaster J, Davidson S, Bromley M, Roberts S, Patterson A, Hunger R, Stratford I, West C: Glucose transporter glut-1 expression correlates with tumor hypoxia and predicts metastasis-free survival in advanced carcinoma of the cervix. Clin Cancer Res 2001, 7:928-934.

56. Comerford KM, Wallace TJ, Karhausen J, Louis NA, Montalto MC, Colgan SP: Hypoxia-inducible factor-1-dependent regulation of the multidrug resistance (MDR1) gene. Cancer Res 2002, 62:3387-3394.

57. Brahimi-Horn MC, Ben-Hall D, llie M, Gounon P, Rouleau M, Hofman V, Doyen J, Mari B, Shoshan-Barmatz V, Hofman P, Poussegur J, Mazure NM: Expression of a truncated active form of VDAC1 in lung cancer associates with hypoxic cell survival and correlates with progression to chemotherapy resistance. Cancer Res 2012, 72:2140-2150.

58. Zhang H, Wong CC, Wei H, Gilkes DM, Korangath $P$, Chaturvedi P, Schito L, Chen J, Krishnamachary B, Winnard PT Jr, Raman V, Zhen L, Mitzner WA, Sukumar S, Semenza GL: HIF-1-dependent expression of angiopoietin-like 4 and L1CAM mediates vascular metastasis of hypoxic breast cancer cells to the lungs. Oncogene 2011, 31:1757-1770.

59. Rohwer N, Weizel M, Daskalow K, Pfander D, Wiedenmann B, Detjen K, Cramer T: Hypoxia-inducible factor 1 a mediated anoikis resistance via suppression a5 integrin. Cancer Res 2008, 68:10113-10120.

60. Chien CW, Lin SC, Lai YY, Lin BW, Lin SC, Lee JC, Tsai SJ: Regulation of CD151 by hypoxia controls cell adhesion and metastasis in colorectal cancer. Clin Cancer Res 2008, 14:8043-8051.

61. Thomas S, Harding M, Smith SC, Overdevest JB, Nitz MD, Frierson HF Jr, Tomlins SA, Kristiansen G, Theodorescu D: CD24 is an effector of HIF-1 driven primary tumor growth and metastasis. Cancer Res 2012, 72:5600-5612.

62. Ke X, Fei F, Chen Y, Xu L, Zhang Z, Huang Q, Zhang H, Yang H, Chen Z, Xing J: Hypoxia upregulates CD147 through a combined effect of HIF-1a and Sp1 to promote glycolysis and tumor progression in epithelial solid tumors. Carcinogenesis 2012, 33:1598-1607.

63. Zhao XY, Chen TT, Xia L, Guo M, Xu Y, Yue F, Jiang Y, Chen GQ, Zhao KW: Hypoxia inducible factor-1 mediates expression of galectin-1: the potential role in migration/invasion of colorectal cancer cells. Carcinogenesis 2010, 31:1367-1375.

64. Aubert S, Fauquette V, Hemon B, Lepoivre R, Briez N, Bernard D, Van Seuningen T, Leroy $X$, Perrais M: MUC1, a new hypoxia inducible factor target gene, is an actor in clear renal cell carcinoma tumor progression. Cancer Res 2009, 69:5707-5715.

65. Sun Q, Zhou H, Binmadi NO, Basile JR: Hypoxia inducible factor-1mediated regulation of semaphorin 4D affects tumor growth and vascularity. J Biol Chem 2009, 284:32066-32074.

66. Wang $Y$, Roche $O$, Xu C, Moriyama EH, Heir P, Chung J, Roos FC, Chen $Y$ Finak G, Milosevic M, Wilson BC, Teh BT, Park M, Irwin MS, Ohh M: Hypoxia promotes ligand-independent EGF receptor signaling via hypoxia-inducible factor-mediated upregulation of caveolin-1. Proc Natl Acad Sci USA 2012, 109:4892-4897.

67. Kim SH, Xia D, Kim SW, Holla V, Menter DG, Dubois RN: Human enhancer of filamentation 1 is a mediator of hypoxia-inducible factor-1a-mediated migration in colorectal carcinoma cells. Cancer Res 2010, 70:4054-4063.

68. Mattauch S, Sachs M, Behrens J: Liprin-a4 is a new hypoxia inducible target gene required for maintenance of cell-cell contacts. Exp Cell Res 2010, 316:2883-2892.

69. Wolf N, Yang W, Dunk CE, Gashaw I, Lye SJ, Ring T, Schmidt M, Winterhager E, Gelihaus A: Regulation of the matricellular proteins CYR61 (CCN1) and NOV (CCN3) by hypoxia-inducible factor-1a and transforming-growth factor- $\beta 3$ in the human trophoblast. Endocrinology 2010, 151:2835-2845.

70. Horii K, Suzuki Y, Kond Y, Akimoto M, Nishimura T, Yamabe Y, Sakaue M, Sano T, Kitagawa T, Himeno S, Imura N, Hara S: Androgen-dependent gene expression of prostate-specific antigen is enhanced synergistically by hypoxia in human prostate cancer cells. Mol Cancer Res 2007, 5:383-391.

71. Liao SH, Zhao XY, Han YH, Zhang J, Wang LS, Xia L, Zhao KW, Zheng Y, Guo $M$, Chen GQ: Proteomics-based identification of two novel direct targets of hypoxia-inducible factor-1 and their potential roles in migration/ invasion of cancer cells. Proteomics 2009, 9:3901-3912. 
72. Pocock R: Invited review: decoding the microRNA response to hypoxia. Plfugers Arch - Eur J Physiol 2011, 461:307-315.

73. Huang $X$, Ding L, Bennewith KL, Tong RT, Welford SM, Ang KK, Story M, Le QT, Giaccia AJ: Hypoxia-inducible mir-210 regulates normoxic gene expression involved in tumor initiation. Mol Cell 2009, 35:856-867.

74. Ying Q, Liang L, Guo W, Zha R, Tian Q, Huang S, Yao J, Ding J, Bao M, Ge C, Yao M, Li J, He X: Hypoxia-inducible microRNA210 augments the metastatic potential of tumor cells by targeting vacuole membrane protein 1 in hepatocellular carcinoma. Hepatology 2011, 54:2064-2075.

75. Huang X, Le QT, Giaccia AJ: MiR-210-micromanager of the hypoxia pathway. Trends Mol Med 2010, 16:230-237.

76. Loayza-Puch F, Yoshida Y, Matsuzaki T, Takahashi C, Kitayama H, Noda M: Hypoxia and RAS-signaling pathways converge on, and cooperatively downregulate, the RECK tumor-suppressor protein through microRNAs. Oncogene 2010, 29:2638-2648.

77. Du R, Sun W, Xia L, Zhao A, Yu Y, Zhao L, Wang H, Huang C, Sun S: Hypoxia-induced down-regulation of microRNA-34a promotes EMT by targeting the Notch signaling pathway in tubular epithelial cells. PLoS One 2012, 7:e30771

78. He M, Wang QY, Yin QQ, Tang J, Lu Y, Zhou CX, Duan CW, Hong DL, Tanaka $T$, Chen GQ, Zhao Q: HIF-1a downregulates miR-17/20a directly targeting p21 and STAT3: a role in myeloid leukemic cell differentiation. Cell Death Differ 2012, doi:10.1038/cdd.2012.130.

79. Chen HY, Lin YM, Chung HC, Lang YD, Lin CJ, Huang J, Wang WC, Lin FM, Chen Z, Huang HD, Shyy JY, Liang JT, Chen RH: miR-103/107 promote metastasis of colorectal cancer by targeting the metastasis suppressors DAPK and KLF4. Cancer Res 2012, 72:3631-3641.

80. Yamakuchi M, Lotterman CD, Bao C, Hruban RH, Karim B, Mendell JT, Huso D, Lowenstein CJ: p53-induced microRNA-107 inhibits HIF-1 and tumor angiogenesis. Proc Natl Acad Sci USA 2010, 107:6334-6339.

81. Voellenkle C, Rooij JV, Guffanti A, Brini E, Fasanaro P, Isaia E, Croft L, David M, Capogrossi MC, Moles A, Felsani A, Martelli F: Deep-sequencing of endothelial cells exposed to hypoxia reveals the complexity of known and novel microRNAs. RNA 2012, 18:472-484.

doi:10.1186/1423-0127-19-102

Cite this article as: Tsai and Wu: Hypoxia-regulated target genes

implicated in tumor metastasis. Journal of Biomedical Science 2012 19:102.

\section{Submit your next manuscript to BioMed Central and take full advantage of:}

- Convenient online submission

- Thorough peer review

- No space constraints or color figure charges

- Immediate publication on acceptance

- Inclusion in PubMed, CAS, Scopus and Google Scholar

- Research which is freely available for redistribution 